\title{
Date and Time of Disease Response Assessment
}

National Cancer Institute

\section{Source}

National Cancer Institute. Date and Time of Disease Response Assessment. NCI

Thesaurus. Code C117389.

The date and time of disease response data collection. 